\title{
Morphology and ecology of Daphnia middendorffiana, Fisher 1851 (Crustacea, Daphniidae) from four new populations in the Alps
}

\author{
Rocco TIBERTI \\ Department of Animal Biology, University of Pavia, Via Ferrata 1, I-27100 Pavia, Italy \\ e-mail: fitibert@inwind.it
}

\begin{abstract}
Daphnia middendorffiana has an arctic, circumpolar distribution, with some isolated southerly populations restricted to mountainous areas, including the Alps. In this paper, new records of Daphnia middendorffiana on the Alps are reported. The species was regularly recorded in several samples collected from 2006 to 2009 in four high altitude lakes in the Gran Paradiso National Park (GPNP) during the ice free period. This is the third finding for the Alps and the described populations are the largest. Chemical and morphometric features of the lakes are provided, the morphology of the Daphnia middendorffiana from GPNP is described as well as some aspects concerning its ecology. The studied lakes are small, oligotrophic (total phosphorus ranged from 0 to $7 \mu \mathrm{g} L^{-1}$ ) and well preserved from acidification risk (pH ranged from 6.45 to 8.14 ). D. middendorffiana is the largest zooplanktonic crustacean inhabiting the Alpine lakes in GPNP reaching $3.43 \mathrm{~mm}$ in length; the morphological analysis noted some differences within the studied populations; however there is a clear resemblance to the only Alpine population previously described (from Central Alps, Bognanco Valley, Lake Campo IV) and to the arctic populations. D. middendorffiana in GPNP lives at low density levels, reaching higher densities in late August and early September. No males have been found during the sample campaign confirming its ability to produce asexual viable diapauses eggs. This study confirms the attitude of this species for cold and oligotrophic waters and increases the current knowledge on the geographical distribution, morphology and ecology of this species in Alpine environments. The finding of D. middendordorffiana in the GPNP poses interesting issues concerning the phylogeography of Alpine Daphnia middendorffiana, as well as raising need for conservation efforts aimed at keeping the populations safe from several global and local threats, such as climate warming and the ecological impact of alien species.
\end{abstract}

Key word: zooplankton, isolated population, introduced fish, Gran Paradiso National Park, Alpine lake

\section{INTRODUCTION}

Daphnia middendorffiana has an arctic, circumpolar distribution (Brooks 1957; Manuilova 1964; Hobaek \& Weider 1999) and is one of the most widespread Daphnia species in arctic freshwater ecosystems, extending its range to the northernmost land in Greenland $\left(83^{\circ} 30^{\prime} \mathrm{N}\right)$ (Haney \& Buchanan 1987). There are also isolated southerly populations in the Rockies (Brooks 1957), a record (as D. gibbosa) from Poland (Hellich 1877 ) and some other populations are reported in Argentina (Vega \& Clause 2000). D. middendorffiana has been reported also in the Alps and its presence is known since several decades (Brooks 1957; Ferrari 1967). In spite of the extensive zooplankton taxonomic surveys conducted through the Alps (Tonolli \& Tonolli 1951; Giussani et al. 1986; Angeli et al. 2002; Angeli \& Tavernini 2006) just two records were known for this species until now: Lake Campo IV (2293 m a.s.l.) in the Bognanco Valley, Italy (Ferrari 1967, 1970) and Lake Antermoia (2496 m a.s.l.) in the Avisio catchment, Italy (Angeli \& Tavernini 2006).

Four new records of $D$. middendorphiana from high altitude fishless lakes in the Gran Paradiso National Park (GPNP) are reported for the first time in this paper. The examined species was found during a monitoring campaign that included several other lakes, regularly sampled since 2006-2007. These lakes were sampled since 2006 or 2007. The results concerning D. middendorphiana presented in this paper are supported by data collected in four years of monitoring activities (20062009). Particular emphasis is given to the morphology of the studied populations and its variability as a diagnostic taxonomic trait (Margaritora 1985; Haney \& Buchanan 1987; Manuilova 1964) and as an adaptive ecological feature (Balseiro \& Vega 1994).

\section{METHODS}

\subsection{Study area}

Gran Paradiso National Park (GPNP) is located between $45^{\circ} 25^{\prime}$ and $45^{\circ} 45^{\prime} \mathrm{N}$ and between $7^{\circ}$ and $7^{\circ} 30^{\prime}$ $\mathrm{W}$ in the Western Italian Alps. The protected area shows a large altitudinal extension (between 800 and $4061 \mathrm{~m}$ ) and a typical Alpine climate.

D. middendorphiana was found in 4 lakes belonging to the catchments of rivers Orco and Dora di Savarenche, all included within the territory of GPNP: the lakes Nivolet Superiore, Trebecchi Inferiore, Trebecchi Superiore and Lillet are all above $2500 \mathrm{~m}$ a.s.l. and they are not affected by hydromorphological alterations (Tiberti et al. 2010). In this paper, toponims of the lakes will be replaced by the following abbreviations: 
Tab. 1. Geographic, morphometric and chemical features of GPNP studied lakes and catchment carachteristics (Tiberti et al. 2010). $\mathrm{Z}_{\mathrm{m}}$ : maximum depth; A: area; L: perimeter; V: volume; B: catchment area. Geology - AG: cathment entirely composed by Acidic Gneiss; geology - CS: catchment dominated by thick covering of Calcareous Schists. Average values of the main chemical features during the zooplankton sampling campaign: $\mathrm{C}$ : conductivity at $20^{\circ} \mathrm{C}$; Alk: total alkalinity; TP: total phosphorus; TN: total nitrogen; TOC: total organic carbon.

\begin{tabular}{|c|c|c|c|c|c|}
\hline & & NIVSUP & TREINF & TRESUP & LILLET \\
\hline Latitude N & & $45^{\circ} 28^{\prime} 41^{\prime \prime}$ & $45^{\circ} 30^{\prime} 08^{\prime \prime}$ & $45^{\circ} 30^{\prime} 07^{\prime \prime}$ & $45^{\circ} 28^{\prime} 00^{\prime \prime}$ \\
\hline Longitude E & & $07^{\circ} 08^{\prime} 55^{\prime \prime}$ & $07^{\circ} 08^{\prime} 48^{\prime \prime}$ & $07^{\circ} 08^{\prime} 40^{\prime \prime}$ & $07^{\circ} 12^{\prime} 26^{\prime \prime}$ \\
\hline Altitude & (m) & 2538 & 2723 & 2729 & 2765 \\
\hline $\mathrm{Z}_{\mathrm{m}}$ & (m) & 17.1 & 8.1 & 7.5 & 13.2 \\
\hline A & $\left(\mathrm{m}^{2}\right)$ & 34482 & 14812 & 14172 & 36249 \\
\hline $\mathrm{L}$ & (m) & 986 & 493 & 565 & 846 \\
\hline V & $\left(10^{3} \mathrm{~m}^{3}\right)$ & 162.1 & 61.8 & 48.9 & 233.1 \\
\hline B & (ha) & 29.11 & 43.76 & 23.66 & 91.86 \\
\hline Geology & & AG & CS & CS & AG \\
\hline $\mathrm{pH}$ & & 7.07 & 7.93 & 7.98 & 7.38 \\
\hline $\mathrm{C}$ & $\left(\mu \mathrm{S} \mathrm{cm}^{-1}\right)$ & 21.69 & 87.58 & 100.55 & 43.90 \\
\hline Alk & $\left(\right.$ meq L $\left.^{-1}\right)$ & 0.20 & 0.94 & 1.07 & 0.40 \\
\hline $\mathrm{TP}$ & $\left(\mu \mathrm{g} \mathrm{L}^{-1}\right)$ & 2.7 & 2.3 & 1.4 & 2.0 \\
\hline $\mathrm{TN}$ & $\left(\mathrm{mg} \mathrm{L}^{-1}\right)$ & 0.18 & 0.12 & 0.13 & 0.27 \\
\hline TOC & $\left(\mathrm{mg} \mathrm{L}^{-1}\right)$ & 0.58 & 0.48 & 0.45 & 0.25 \\
\hline
\end{tabular}

Nivolet superiore - NIVSUP, Trebecchi Inferiore TREINF, Trebecchi Superiore - TRESUP, Lillet LILLET. Main geographical, morphological and watershed data are based on Tiberti et al. (2010) (Tab. 1). Chemical features (Tab. 1) are partially based on Tiberti et al. (2010) and available only for the last two years of study.

The lakes are placed in two geologically separated areas: the first is entirely dominated by acidic gneiss (surrounding NIVSUP and LILLET), while the second is dominated by thick covering of calcareous schists variously metamorphosed (surrounding TRESUP and TREINF) (Leporati et al. 1999). The geology affects the vegetation development in the watershed (Scotta et al. 1999) as well as the hydrochemistry of the lakes (Tiberti et al. 2010). The studied lakes are well preserved by acidification risk ( $\mathrm{pH}$ ranges from 6.45 to 8.29 and alkalinity from 0.16 to $1.08 \mathrm{meq} \mathrm{L}^{-1}$ ) and their conductivity is low (from 20.3 to $101.5 \mu \mathrm{S} \mathrm{cm}^{-1}$ ). Concerning the nutrient contents, according to the Redfield ratio, phosphorus is the phytoplankton growth limiting element and is assumed to have a leading role in shaping the biotic community (Tiberti et al. 2010); its concentration is an index of oligotrophy and ultraoligotrophy. In the studied lakes the ice cover lasts for most of the year, from November until late June or even late July. Measurements of temperature profiles show that only deeper lakes (LILLET and NIVSUP) undergo stable stratification during the ice free period, while shallow lakes (TREINF and TRESUP) mostly show slightly depth-decreasing temperature gradients, suggesting that thermal stratification would be likely unable to offer resistance to wind mixing effects (Tiberti et al. 2010). Low values of oxygen saturation can occur at the bottom just after surface ice melting (17\% oxygen saturation was observed in NIVSUP on June 30, 2008), probably because of Winter oxygen consumption under the ice cover, while all the lakes were well oxygenated late in the season (Tiberti et al. 2010).

\subsection{Sampling and analytical methods}

Monitoring activity in NIVSUP, TREINF and TRESUP started during 2006 and one year later in LILLET. Zooplankton samples were collected at least twice every year during the ice free period until 2009. Unfortunately only one zooplankton sample is available for TREINF and TRESUP in 2006. The first sample was collected at the beginning of summer (June or July), the last late in the season (August or September) to observe the zooplankton community both in its early stages and in the mature stages. Moreover, during summer 2009, NIVSUP and TRESUP were sampled at regular intervals of time (every 15 days) to obtain results on the ecological dynamics of $D$. middendorffiana and the whole zooplankton community during the season.

Zooplankton samples were collected in the deepest point of the lakes. The zooplankton net (an open net with $48 \mu \mathrm{m}$ mesh size) was towed vertically from the bottom to the surface. Sample fixation in $4 \%$ formaldehyde was carried out in the field as early as possible to avoid damage to animal tissues by bacterial action and autolysis (Goswami 2004). Zooplankton taxa in the samples were identified following Dussart (1969), Harding \& Smith (1974), Barioni \& Gelmini (1983), Stella (1984) and Margaritora (1985). The number of individuals of each taxon in each sample were counted following Edmonson (1971) in order to obtain density data.

\subsection{Morphological analysis}

A sample of 163 D. middendorffiana specimens, collected over four years at different times from all the studied lakes, underwent more detailed morphological 
analysis. A series of relevant morphological traits (Haney \& Buchanan 1987) was observed, such as the pigmentation of the carapace, the shape of the head and of the abdominal processes, the presence of a gape between ventral margin of the head and carapace, the number of anal teeth, the number of denticles in the middle pecten and the number of eggs in the brood chamber. Moreover the body length of 302 D. middendorffiana specimens have been measured (from the top of the head to the base of the tail spine) while the tail spine length was measured in a smaller subsample of 126 D. middendorffiana specimens.

\subsection{Data analysis}

The factors influencing some biometric variables such as the body length (Size) and the length of tail spine (Spine), were determined with linear mixed-effects models (LME) fitted by Restricted Maximum Likelihood (REML) to avoid pseudoreplication due to repeated sampling of the same lakes at different times. The LMEs were fitted following Zuur et al. (2009) using the nlme package (Pinheiro et al. 2010) of the statistical environment R version 2.12.1 (R Development Core Team 2010). A "beyond optimal model", where the fixed component contains all explanatory variables and as many interactions as possible, has been used to find the optimal structure of the random component evaluated considering the difference between the Akaike Information Criteria (AIC difference). Once the optimal random structure was found, the optimal fixed effect structure was determined with a stepwise method by comparing the same models fitted with Maximum Likelihood (ML) with a Likelihood Ratio Test. Only the results of the optimal model refitted by RELM are provided in this article. The number of eggs or embrios carried by the measured individual (Eggs), the size of the measured individuals (Size), the year of sampling (Year), the number of days since June $15^{\text {th }}$ of the year of sampling (Day) and biologically meaningful interactions among these variables were included to the "beyond optimal model" as fixed effects. In the model in which "Size" is fitted as dependent variable, "Eggs" was included among the fixed effects as a binary variable (presence/absence of eggs or ephippia). The lake identity (Lake) was included in all models as a random effect.

\section{RESULTS}

\subsection{Morphological features}

A detailed morphological analysis was conducted on 163 D. middendorffiana specimens. Distinct brown pigmentation extending to the dorsal exoskeleton and often to the proximal segments of antennas is the most striking feature of $D$. middendorffiana and has been regularly observed in all the studied populations. The head of the observed individuals was separated from the valves by a gap and sloped quickly after the optic vescicle, producing an acute angle with body axis; a slight spinulation of ventral and dorsal margin of valves was always present and was more marked in the tail spine region. In the large, mature individuals the 1 st post abdominal process was lint and longer than the $2^{\text {nd }}$. The number of anal teeth ranged between 11 and 23 , but there were some differences in the range of variation depending on the studied lakes (12-22 in NIVSUP; 1123 in TREINF; 17-22 in TRESUP; 11-18 in LILLET). The number of denticles in the middle pecten ranged between 5 and 11; as in the case of anal teeth, some differences were detectable among the studied lakes: while in NIVSUP and LILLET there were up to 11 denticles, in TREINF and TRESUP the number of denticles did not exceeded seven. The number of parthenogenetic eggs retained inside the brood chamber could reach 15 (in a large, $3.35 \mathrm{~mm}$ long, D. middendorffiana, sampled in NIVSUP on 24 June, 2007) but it was usually lower.

The length (Size) of 306 D. middendorfiana specimens (tail spine excluded) ranged from $0.60 \mathrm{~mm}$ (13/7/07, LILLET) to $3.43 \mathrm{~mm}$ (24/6/2007, NIVSUP). LME models with "Size" as dependent variable were improved by adding the random effect Lake (AIC difference $=112.11$ ), showing size variability depending on the population of origin. The LME models indicated the size was negatively related with the number of Days from the $15^{\text {th }}$ of June and was positively affected by the presence of Eggs, while Year and all the interactions terms among variables were dropped from the initial model (Tab. 2), suggesting that the size of D. middendorffiana is significantly larger at the beginning of the ice free period and in egg carrying females.

Tab. 2. Fixed effect results from Linear Mixed Effect models with body length (Size) of Daphnia middendorffiana as the dependent variable, Lake as a random grouping factor, a random intercept, and Day, Year and Eggs as independent variables. Model is based on 306 observations from 4 lakes.

\begin{tabular}{|c|c|c|c|c|}
\hline & Coeff. & $d f$ & $F$ & $p$ \\
\hline \multicolumn{5}{|c|}{ Terms included in the model } \\
\hline Day & -0.76 & 1.296 & 37.68 & $\leq 0.0001$ \\
\hline Eggs & & 1.296 & 8.77 & $\leq 0.01$ \\
\hline \multicolumn{5}{|c|}{ Rejected terms } \\
\hline Year & 0.01 & 1.294 & 0.14 & 0.70 \\
\hline Eggs*Day & 0.00 & 1.295 & 0.75 & 0.38 \\
\hline
\end{tabular}

The tail spine length (range: $0.05-0.58 \mathrm{~mm}$ ) from 126 D. middendorffiana specimens was analyzed in the same way. Adding the random effect Lake improved the models (AIC difference $=17.51$ ). Spine length was inversely proportional to Size (Fig. 1), showing a negative allometric development of tail spine; the main results are summarized in table 3 .

\subsection{Ecological features}

A total of 40 zooplankton samples were analyzed since 2006 (14 from NIVSUP, 7 from TREINF, 13 from 


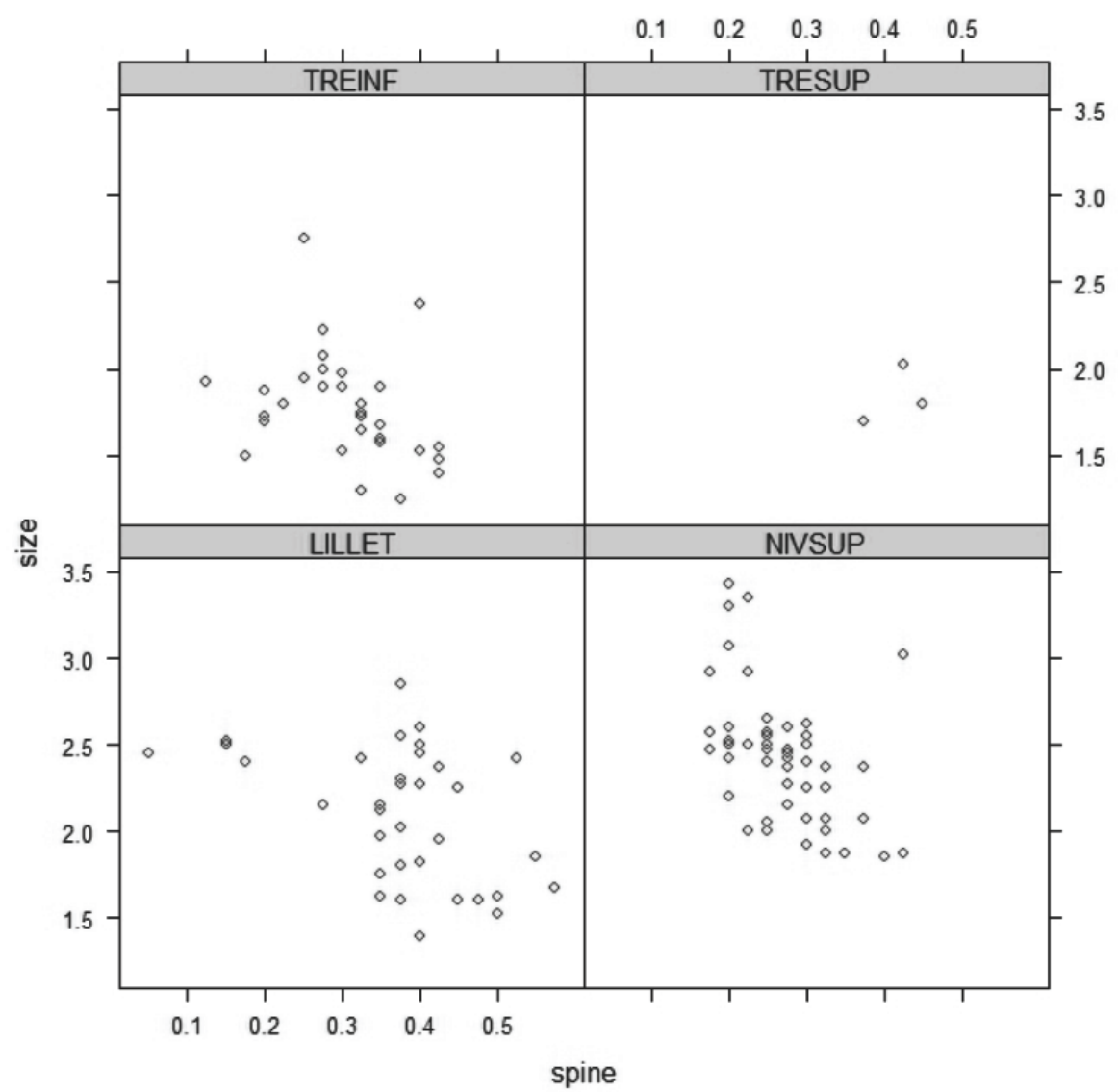

Fig. 1. Negative allometric development of tail spine in Daphnia middendorffiana populations from GPNP.

TRESUP and 6 from LILLET). D. middendorffiana was regularly found in samples from all four study sites (Fig. 2; Tab. 4). Compared with other zooplanktonic species, D. middendorffiana lives in fairly low densities (Tab. 4).

Tab. 3. Fixed effect results from Linear mixed Effect models with tail spine length (Spine) of Daphnia middendorffiana as the dependent variable, Lake as a random grouping factor, a random intercept, and Size, Day, Year and Eggs as independent variables. Model is based on 126 observations from 4 lakes.

\begin{tabular}{lcccc}
\hline & Coeff. & $d f$ & $F$ & $p$ \\
\hline \multicolumn{2}{l}{ Terms included in the model } \\
Size & -0.10 & 1.118 & 24.61 & $\leq 0.0001$ \\
Day & 0.01 & 1.118 & 6.34 & $\leq 0.05$ \\
Eggs & 0.00 & 1.118 & 4.25 & $\leq 0.05$ \\
$\begin{array}{l}\text { Rejected terms } \\
\text { Eggs*Day }\end{array}$ & 0.00 & 1.114 & 0.03 & 0.86 \\
Year & 0.00 & 1.115 & 0.12 & 0.73 \\
Size*Day & 0.00 & 1.116 & 0.30 & 0.59 \\
Size*Eggs & -0.02 & 1.117 & 2.44 & 0.12 \\
\hline
\end{tabular}

The maximum density was found in NIVSUP, reaching 314 individuals $\mathrm{m}^{-3}$ (August 20, 2008), but it never exceeded one hundred individuals in all other samples. In comparison, a very similar species such as Daphnia gr. longispina can exceed 10,000 individuals $\mathrm{m}^{-3}$ within the same samples. D. middendorffiana has been found also in samples collected early in the season, often when the lakes were still mostly covered by ice. However most of the specimens were sampled later in the season. Some information concerning the ecological dynamics of $D$. middendorffiana have been obtained in lakes NIVSUP and TRESUP, where its density was measured every 15 days during 2009, confirming that the highest densities are registered between mid-August and early September (Fig. 2).

The studied populations of $D$. middendorffiana share the same environment with other zooplanktonic crustaceans and rotifers (Tab. 5): LILLET is the only lake where $D$. middendorfiana does not live in simpatry with Daphnia gr. longispina (in TREINF and TRESUP some individuals have been identified as Daphnia rosea belonging to the Daphnia longispina species complex), but otherwise it always coexists with Arctodiaptomus alpinus and Cyclops gr. abyssorum. In a few cases also Eucyclops serrulatus, Chydorus sphaericus, Alona quadrangularis and Acropaerus harpae were found in the studied lakes. The zooplankton community in GPNP lakes is complemented by some species of rotifers such as Keratella quadrata (the most common rotifer in the studied lakes), Polyarthra gr. dolichoptera, Synchaeta gr. stylata-pectinata, Notholca squamula, Notholca labis, Keratella cochlearis and Lecane gr. lunaris. 
Tab. 4: Zooplankton community structure, Daphnia middendorffiana density \pm sd and its mean length \pm sd; DAPMID: Daphnia middendorffiana; N: number of measured individuals; NAU: nauplii; ARC: Arctodiaptomus alpinus; CYC: Cyclops gr. abyssorum; EUC: Eucyclops serrulatus; DAP: Daphnia gr. longispina; CHY: Chydorus sphaericus; ACR: Acropaerus harpae; ALO: Alona quadrangularis; ROT: rotifera; KER: Keratella quadrata; POL: Polyarthra gr. dolichoptera; KCO: Keratella cochlearis; NSQ: Notholca squamula; NLA: Notholca labis; LLU: Lecane gr. lunaris; SYN: Synchaeta gr. stylata-pectinata; $(+)$ : $<10$ individuals $\mathrm{m}^{-3} ;(*)$ : from 10 to 100 individuals $\mathrm{m}^{-3} ;(* *)$ : from 100 to 1000 individuals $\mathrm{m}^{-3} ;(* * *)$ : from 1000 to 10000 individuals $\mathrm{m}^{-3} ;(* * * *):>10000$ individuals $\mathrm{m}^{-3}$.

\begin{tabular}{|c|c|c|c|c|c|c|c|c|c|c|c|c|c|}
\hline Lake & Data & $\begin{array}{l}\text { DAPMID } \\
\mathrm{N} \mathrm{m}^{-3}\end{array}$ & $\begin{array}{l}\text { Length } \\
\mathrm{mm}\end{array}$ & $\mathrm{N}$ & NAU & ARC & CYC & EUC & DAP & $\mathrm{CHY}$ & ACR & ALO & ROT \\
\hline NIVSUP & $12 / 07 / 06$ & $4 \pm 8.8$ & 1.85 & 1 & $* *$ & $* *$ & $* *$ & + & $*$ & & & & $\mathrm{KER}^{* * * * ;} \mathrm{POL}+; \mathrm{KCO}^{*}$; $\mathrm{NSQ}^{*}$ \\
\hline NIVSUP & $27 / 08 / 06$ & $34 \pm 11.3$ & $2.02 \pm 0.25$ & 15 & & $*$ & $* *$ & & $* *$ & & & & $\mathrm{KER}^{*} ; \mathrm{KCO} *$ \\
\hline NIVSUP & $24 / 06 / 07$ & $2 \pm 2.9$ & $3.15 \pm 0.17$ & 6 & $* *$ & $* *$ & $* *$ & + & $*$ & & & & $\mathrm{KER}^{* *} ; \mathrm{POL}^{*} ; \mathrm{KCO}+$ \\
\hline NIVSUP & $20 / 08 / 07$ & $314 \pm 76.2$ & $2.06 \pm 0.30$ & 106 & & $* *$ & $* * *$ & $*$ & $* * *$ & & & + & \\
\hline NIVSUP & $30 / 06 / 08$ & & & & $* *$ & & $*$ & & & & & & $\mathrm{KER}^{* * * *} ; \mathrm{POL}^{* *} ; \mathrm{NSQ}^{* *}$ \\
\hline NIVSUP & $01 / 09 / 08$ & & & & & $* *$ & $* *$ & $*$ & $*$ & & + & + & $\mathrm{KER}^{* *} ; \mathrm{POL}^{* * *} ; \mathrm{NSQ}^{*}$ \\
\hline NIVSUP & 08/07/09 & $8 \pm 4.4$ & $2.65 \pm 0.17$ & 4 & $* *$ & & $* *$ & & $*$ & & & & $\mathrm{KER}^{* * *} ; \mathrm{KCO}+; \mathrm{NSQ}^{+}$ \\
\hline NIVSUP & $21 / 07 / 09$ & & & & $* *$ & + & $* *$ & & + & & & & $\mathrm{KER}^{* * *}$ \\
\hline NIVSUP & $03 / 08 / 09$ & $2 \pm 5.4$ & $2.55 \pm 0.50$ & 5 & + & $* *$ & $* *$ & & $*$ & & & & $\mathrm{KER}^{* *}$ \\
\hline NIVSUP & $19 / 08 / 09$ & & & & $*$ & $* * *$ & $* *$ & + & $* *$ & & & & $\mathrm{KER}^{* *}$ \\
\hline NIVSUP & $02 / 09 / 09$ & $52 \pm 27.0$ & $2.04 \pm 0.52$ & 8 & $* *$ & $* *$ & $* * *$ & & $* * *$ & & & & $\mathrm{KER}^{* *} ; \mathrm{POL}+$ \\
\hline NIVSUP & $17 / 09 / 09$ & $20 \pm 14.1$ & $2.35 \pm 0.18$ & 5 & $*$ & $* *$ & $* *$ & $*$ & $* * *$ & & & & KER* \\
\hline NIVSUP & $02 / 10 / 09$ & $7 \pm 10$ & $2.34 \pm 0.41$ & 2 & $* *$ & $*$ & $* *$ & & $* * *$ & & & & $\mathrm{KER}^{+}$; $\mathrm{POL}^{*}$; NSQ+ \\
\hline NIVSUP & $14 / 10 / 09$ & & & & $*$ & + & $*$ & & $* *$ & & & & $\mathrm{POL}^{* *}$ \\
\hline TREINF & $16 / 07 / 06$ & $31 \pm 26.8$ & $2.08 \pm 0.48$ & 9 & $* *$ & $* *$ & $* * *$ & & $* *$ & $*$ & & & $\mathrm{KER}^{* *} ; \mathrm{KCO} *$ \\
\hline TREINF & $30 / 06 / 07$ & & & & $* *$ & $* *$ & $* *$ & & $*$ & & & & $\mathrm{KER} * * *$ \\
\hline TREINF & $22 / 08 / 07$ & $15 \pm 9.9$ & $1.65 \pm 0.33$ & 9 & $*$ & $*$ & $* * *$ & & $*$ & * & & $*$ & $\mathrm{KER}^{*}$ \\
\hline TREINF & $10 / 07 / 08$ & & & & $* *$ & $* *$ & $* * *$ & & $*$ & & & & $\mathrm{KER}^{* * *} ; \mathrm{POL}+$; NSQ+ \\
\hline TREINF & $23 / 08 / 08$ & $21 \pm 2.3$ & $1.41 \pm 0.24$ & 13 & $* *$ & $*$ & $* *$ & + & $* * *$ & + & & & $\mathrm{KER}^{*} ; \mathrm{POL}^{* *} ; \mathrm{NSQ}+$ \\
\hline TREINF & $07 / 07 / 09$ & & & & $* *$ & $*$ & $* *$ & & $*$ & + & & & $\mathrm{KER}^{* *} ; \mathrm{KCO}^{*}$ \\
\hline TREINF & $18 / 08 / 09$ & $91 \pm 23.8$ & $1.90 \pm 0.37$ & 27 & $*$ & $* * *$ & $* *$ & $*$ & $* * *$ & $*$ & & + & $\mathrm{KER}^{* *}$ \\
\hline TRESUP & $15 / 07 / 06$ & $20 \pm 13.7$ & $1.76 \pm 0.59$ & 6 & $* * *$ & $* * *$ & $* * *$ & + & $* *$ & & & & $\mathrm{KER}^{* *} ; \mathrm{KCO} * *$ \\
\hline TRESUP & $30 / 06 / 07$ & $2 \pm 3.1$ & 2.00 & 1 & $* *$ & $* *$ & $* * *$ & & $*$ & + & & & $\mathrm{KER}^{* * *}$ \\
\hline TRESUP & $22 / 08 / 07$ & & & & & $*$ & $* *$ & & $* * *$ & & & $*$ & \\
\hline TRESUP & $09 / 07 / 08$ & $14 \pm 3.6$ & $1.37 \pm 0.67$ & 4 & $* * *$ & $* *$ & $* * *$ & & $*$ & & + & + & $\mathrm{KER}^{* * * *} ; \mathrm{POL}^{*} ; \mathrm{NSQ}^{*}$ \\
\hline TRESUP & $23 / 08 / 08$ & & & & $* *$ & $*$ & $* *$ & + & $* *$ & & & $*$ & $\mathrm{KER}^{* *}$; $\mathrm{POL}^{* *}$; NSQ*${ }^{*}$ NLA*; LLU+ \\
\hline TRESUP & $07 / 07 / 09$ & & & & $* * *$ & $*$ & $* * *$ & & + & & & & $\mathrm{KER}^{* * *} ; \mathrm{KCO}+; \mathrm{NSQ}^{+}$ \\
\hline TRESUP & $20 / 07 / 09$ & & & & $* * *$ & $* *$ & $* * *$ & + & $* *$ & & & & $\mathrm{KER}^{* * *} ; \mathrm{KCO}+; \mathrm{NSQ}^{+}$ \\
\hline TRESUP & $04 / 08 / 09$ & $4 \pm 9.9$ & $2.12 \pm 0.06$ & 3 & $* *$ & $* * *$ & $* *$ & & $* *$ & & & & $\mathrm{KER}^{* *}$ \\
\hline TRESUP & $18 / 08 / 09$ & $20 \pm 20.8$ & $1.86 \pm 0.19$ & 5 & $*$ & $* *$ & $* * *$ & & $* * *$ & + & & & $\mathrm{KER}^{* *} ; \mathrm{NLA}+$ \\
\hline TRESUP & $01 / 09 / 09$ & $7 \pm 14.8$ & 2 & 1 & * & $*$ & $* *$ & & $* * * *$ & & & & $\mathrm{KER}^{* *}$ \\
\hline TRESUP & $18 / 09 / 09$ & & & & $*$ & $* *$ & $*$ & & $* * *$ & + & & & \\
\hline TRESUP & $01 / 10 / 09$ & & & & & $*$ & $* *$ & & $* * * *$ & & & $*$ & KER* \\
\hline TRESUP & $13 / 10 / 09$ & & & & + & + & + & & $*$ & + & & & KER* \\
\hline LILLET & $03 / 07 / 07$ & $3 \pm 4.2$ & $1.67 \pm 0.92$ & 4 & $* * *$ & $* *$ & $*$ & & & & & & $\mathrm{KER}^{*}$; SYN* \\
\hline LILLET & $18 / 08 / 07$ & $24 \pm 1.9$ & $1.49 \pm 0.51$ & 26 & $* *$ & $* * *$ & $* *$ & & & & & & KER* \\
\hline LILLET & $13 / 07 / 08$ & $1 \pm 0.7$ & $1.24 \pm 0.81$ & 4 & $* * *$ & + & + & & & & & & $\mathrm{KER}^{*} ; \mathrm{POL}^{*} ; \mathrm{SYN}^{* *}$ \\
\hline LILLET & $26 / 08 / 08$ & $48 \pm 5.9$ & $1.44 \pm 0.57$ & 28 & $* *$ & $* * *$ & $* *$ & & + & & & & $\mathrm{KER}^{* * *} ; \mathrm{POL}^{* * *}$ \\
\hline LILLET & $28 / 07 / 09$ & & & & $* * *$ & & $*$ & & & & & & $\mathrm{KER}^{* *} ; \mathrm{KCO}+$; $\mathrm{NSQ}+$; NLA + ; $\mathrm{SYN}^{*}$ \\
\hline LILLET & $29 / 08 / 09$ & $16 \pm 9.2$ & $0.97 \pm 0.21$ & 13 & $* *$ & $* *$ & $*$ & & & & & & $\mathrm{KER}^{*} ; \mathrm{KCO}+$ \\
\hline
\end{tabular}

Females carrying parthenogenetic eggs were found throughout the summer, even early in the season. Individuals with diapausing eggs (or ephippia) were found only once in NIVSUP on 2 September, 2009. Throughout the sampling campaign, no male has been identified.

\section{DISCUSSION}

\subsection{Morphology}

The observed morphology was consistent with the one reported by Ferrari (1967) from Lake Campo IV (central Italian Alps) or by Haney \& Buchanan (1987) from the Arctic regions (Tab. 5). The pigmentation, the dorsal margin of head, the abdominal processes, the gape between head and carapace and the body length show the same features both in the Alpine and Arctic populations. However, the GPNP populations share with the Arctic populations the same number of anal teeth and denticles in the middle pecten, markedly higher than in Campo IV populations. Variability in both the number of anal teeth and denticles in the middle pecten was found also within the GPNP populations: for example, the maximum number of anal teeth was 18 in LILLET, very similar to the number observed in Campo IV. The same situation was recorded for the number of denticles of the middle pecten: in TREINF and TRESUP its number did not exceeded seven (in Campo IV it was six), while in NIVSUP and LILLET there were up to 11 denticles. Any morphological variations within GPNP populations and among GPNP, CampoIV and arctic populations could be caused either by environmental pressures or genetic differences, which should be cleared out by further genetic analysis. Both morphological and genetic variability can be used as valuable information for studying $D$. middendorffiana distribution and geographical separation. 

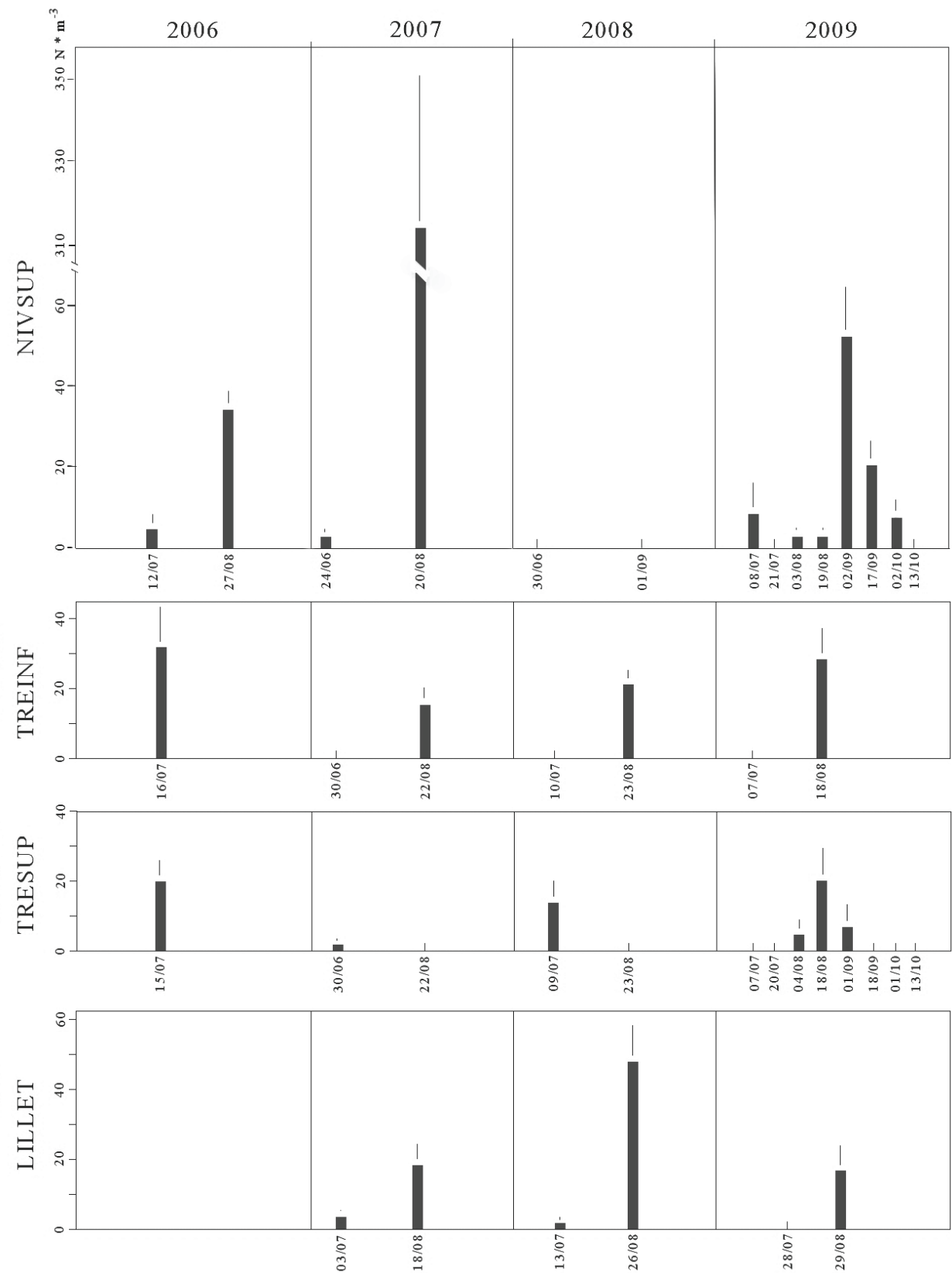

Fig. 2. Date of sampling and abundances +1 se of Daphnia middendorffiana in GPNP populations.

Tab. 5. A comparison of morphology of Daphnia middendorffiana from GPNP, Campo IV (Ferrari 1967) and Arctic populations (Haney \& Buchanan 1987).

\begin{tabular}{|c|c|c|c|}
\hline & This study & Campo IV lake & Arctic \\
\hline Pigmentation & Yes & Yes & Yes \\
\hline Dorsal head margin & Nearly straight, acute angle with body axis & Nearly straight, acute angle with body axis & Nearly straight, $45^{\circ}$ angle with body axis \\
\hline Gap & Present & Present & Usually present \\
\hline Spinulation & Extends on to anterior half of the margin & Extends on to anterior half of the margin & Often extends on to anterior half of the margin \\
\hline Abdominal processes & Length of $1^{\text {st }}$ longer than the length of $2^{\text {nd }}$ & Length of $1^{\text {st }}$ longer than the length of $2^{\text {nd }}$ & Length of $1^{\text {st }}$ about two time the length of $2^{\text {nd }}$ \\
\hline Anal teeth & 23 & 17 & 24 \\
\hline Middle pectin & $5-11$ & 6 & $5-10$ \\
\hline Maximum Size & $3.43 \mathrm{~mm}$ & More than $3 \mathrm{~mm}$ & Up to $3.5 \mathrm{~mm}$ \\
\hline Tail spine & Short, $2-34 \%$ body length & Short, $10-24 \%$ body length & Up to $33 \%$ length of valves; rarely short \\
\hline $\begin{array}{l}\text { Tail spine negative allometric } \\
\text { development }\end{array}$ & Yes & Yes & Yes \\
\hline Maximum number of retained eggs & 15 & 16 & - \\
\hline
\end{tabular}


Ferrari (1970) observed up to 16 parthenogenetic eggs retained inside the brood chamber in specimens from Campo IV population. The results from the present study confirm this observation, as the maximum number of parthenogenetic eggs retained inside the brood chamber was 15 , but usually lower.

The body length of $D$. middendorffiana is significantly larger at the beginning of the ice free period and in egg carrying females. Margaritora (1985) suggested that the life cycle of $D$. middendorffiana is restricted to the ice free period, from June to October. However the presence early in the season of large, often eggs carrying Daphnia shows that they have developed under the ice, suggesting that the life cycle of the species is longer of at least a few weeks. Likewise, Poulsen (1940) and Hilliard \& Tash (1966) observed adult females wintering in deep lakes and producing a subitaneous generation in the spring, just before dying. Probably, as in the arctic populations, even Alpine D. middendorffiana rely on both diapausing and subitaneous eggs when the depth of lakes prevents the freezing of the whole water body.

The studied populations share a negative allometric development of tail spine with the population from Campo IV as well as with Arctic and Andean populations. This inverse proportion between body size and spine length has been linked to predation risk: $D$. middendorffiana shields itself from predation by developing a long spine in the juveniles and a large body size in the adults (Balseiro \& Vega 1994). Both the tail spine and the large body size are considered to be defenses against invertebrate predators (Dodson 1974; Luecke \& O'Brien 1983; Dodson 1984; Balseiro \& Vega 1994), commonly found in fishless lakes (Knapp et al. 2001).

\subsection{Ecology and distribution}

The finding of $D$. middendorffiana in the lakes of the GPNP increases the current knowledge of the geographical distribution of this species with particular reference to its southern range. As in the case of the populations in the Rockies, also in Europe the southern populations live on mountains, where $D$. middendorffiana can meet its ecological requirements. The findings described in this study are the third for the Alps and the studied populations are the most numerous. This means that this species, though rare, is widespread in the Italian Alps with a remarkable longitudinal range. Moreover, while in its main geographical range, D. middendorffiana can occur in lakes, ponds and also in semipermanent and shallow bodies of water (Haney \& Buchanan 1987; Vega \& Clause 2000), the sampling campaign in GPNP was conducted only in the lakes, while the surrounding smaller aquatic environments were neglected. The same is true for almost all samples collected during every extensive zooplankton taxonomic survey through the Alps (Tonolli \& Tonolli 1951; Giussani et al. 1986; Angeli et al. 2002; Angeli \& Tavernini 2006). Therefore other populations of $D$. middendorf- fiana could occur in the considerable number of ponds and puddles that tipically surround the studied lakes. To better understand the ecology of Alpine populations of D. middendorffiana, future sampling sites should include all these environments.

D. middendorffiana can successfully compete with other zooplankton species in the studied lakes, which provide a cold and oligotrophic suitable environment. Even if D. middendorffiana is considered eurythermal, it has a thermal range for respiration, approximately 5 centigrade degrees lower than that for temperate zone Daphnia sp. (Yurista 1999) and this feature advantages its presence in Alpine lakes. Moreover the life history of D.middendorffiana enables this species to cope with a very short ice-free season by speeding up the production of diapause eggs. Unlike most species of Daphnia, D. middendorffiana is known to be facultatively asexual and to produce viable diapauses eggs without males (Zaffagnini \& Sabelli 1972; Hebert 1981; Yurista 1999), as well as producing ephippia eggs prior to shifting to parthenogenetic reproduction (Stross et al. 1980; Yurista \& O'brien 2001). This ability is also confirmed by the results of this study, where no males were found during the whole sampling campaign. However individuals carrying diapauses eggs were found only once and late in the season, while parthenogenetic individuals were found both early and late in the season. As observed by Edmondson (1955) and Zaffagnini \& Sabelli (1972) the ability to produce asexual diapausing eggs does not imply the impossibility to produce males, but on the Alps, this ability has never been observed in the wild.

All these adaptation for cold temperatures and short seasons enabled $D$. middendorffiana to survive in GPNP lakes. However, in the future, D. middendorffiana might have to compete with species expanding their range under the predicted temperature increase due to climate change in the Alpine area (Magnuson et al. 1997; Holzapfel $\&$ Vinebrooke 2005). The finding of new populations of $D$. middendorffiana can be of help in the design of conservation plans for this species in the Alpine environment in a context of global changes.

A common factor for all the aquatic ecosystems containing $D$. middendorffiana population, is the absence of predatory fish (Vega \& Clause 2000): a considerable number of studies describes the impact of fish introduction in originally fishless lakes, which results in the loss of native species and the degeneration of natural foodweb structure (Knapp et al. 2001; Eby et al. 2006). One of the most obvious prediction is that direct selective predation by visually hunting fish would result in an abundance reduction of more visible, larger and pigmented preys which can lead to their local extinction (Brooks \& Dodson 1965; O'Brien 1987; Brancelj 1999; Knapp et al. 2001; Eby et al. 2006). D. middendorffiana is by far the largest zooplankton species occurring in the GPNP lakes and is strongly pigmented, potentially 
becoming an easy prey. Its presence in the studied lakes can be therefore assumed to depend on the natural absence of fish. Lake Nivolet Inferiore, for instance, is only a few meters distance from NIVSUP and the two lakes are connected by a short river, nevertheless, $D$. middendorffiana has never been found in this lake (personal observation), where a population of Salvelinus fontinalis (an alien salmonid from north America) was introduced. To preserve the population of $D$. middendorffiana in GPNP, it is absolutely necessary to prevent any further introduction of fish. The presence of the national park provides some protection against this threat. Moreover, in accordance with the institutional conservation objectives of GPNP, the establishment of new populations of $D$. middendorffiana should be encouraged through a program of eradication of alien fish. Indeed $D$. middendorffiana could naturally recover following fish removal from egg banks (Manca \& Armiraglio 2002) or thanks to the dispersal of adults and resting eggs (by water flow, wind or animal vectors).

\section{CONCLUSIONS}

This investigation confirms the preference of $D$. middendorffiana for cold and oligotrophic waters and increases the current knowledge of the geographical distribution, morphology and ecology of this species in Alpine environments, rising interesting issues related to its phylogeography. In fact the most interesting feature concerning $D$. middendorffiana Alpine populations is probably related to their geographical isolation: a remarkable distance exists between arctic and Alpine populations, which suggests fascinating, although speculative, hypothesis on the phylogeny of the Alpine D. middendorffiana. A recent series of studies (Weider \& Hobaek 1994; Weider \& Hobaek 1997; Colbourne et al. 1998; Hobaek \& Weider 1999; Weider et al. 1999a, b; Weider \& Hobaek 2003; Paland et al. 2005; Adamowicz et al. 2009) has examined the phylogeography of the artic Daphnia pulex species complex (to which $D$. middendorffiana belongs) discovering that, in spite of a slow rate of morphological evolution in the Daphniidae, morphologically similar taxa showed high levels of genetic divergence. These studies often involved the arctic populations of $D$. middendorffiana from North America, Asia and Europe, including the mountain population from the Rockies, but the Alpine population was never analyzed in this global context.

The finding of $D$. middendondorffiana in the GPNP also raises the need for conservation efforts aimed at keeping the populations safe from several global and local threats, such as climate warming and the ecological impact of alien species. A deeper understanding of the distribution of D. middendorffiana in the GPNP would enhance the ability to address the threats to its conservation. Moreover the presence of D. middendorffiana in fishless lakes should encourage the implementation of programs for the eradication of alien fish, for the benefit of the whole biotic community.

\section{ACKNOWLEDGEMENTS}

The author is grateful Giuseppe Bogliani and Bruno Bassano for their support and contribution to the research program. The author addresses special thanks to Achaz von Hardenberg (Alpine Wildife Research Centre, Gran Paradiso National Park) for the revision of the manuscript, Fiorenza Margaritora for her help in cladoceran identification and ISE-CNR for performing chemical analysis. The Gran Paradiso National Park provided logistic support to the research. Funding for this research was provided by the Gran Paradiso National Park and the European Union within the framework of the FP7 ACQWA Project (Assessment of Climatic change and impacts on the Quantity and quality of Water), Grant Agreement No. 212250.

\section{REFERENCES}

Adamowicz, S.J., A. Petrusek, J.K. Colbourne, P.D.N. Hebert \& J.D.S. Witt. 2009. The scale of divergence: A phylogenetic appraisal of intercontinental allopatric speciation in a passively dispersed freshwater zooplankton genus. Mol. Phylogenet. Evol., 50: 423-436.

Angeli, N. \& S. Tavernini. 2006. Zooplancton. In: Cantonati, M. \& M. Lazzara (Eds), I laghi di alta montagna del bacino del fiume Avisio (Trentino orientale). Monografie del Museo Tridentino di Scienze Naturali, Trento: 129-157.

Angeli, N., M. Cantonati \& G. Rossetti. 2002. Lo zooplancton. In: Cantonati, M., M. Toltoti \& M. Lazzara (Eds), I laghi del parco naturale Adamello-Brenta. Museo Tridentino di Scienze Naturali, Documenti del Parco, Strembo: 153-200.

Balseiro, E.G. \& M. Vega. 1994. Vulnerability of Daphnia middendorffiana to Parabroteas sarsi predation: the role of the tail spine. J. Plankton Res., 16: 783-793.

Braioni, M.G. \& D. Gelmini. 1983. Rotiferi Monogononti (Rotatoria: Monogononta). Guide per il riconoscimento delle specie animali delle acque interne italiane, CNR, 23: $175 \mathrm{pp}$.

Brancelj, A. 1999. The extintion of Arctodiaptomus alpinus (Copepoda) following the introduction of charr into a small Alpine lake Dvojno Jezero (NW Slovenia). Aquat. Ecol., 33: 355-361.

Brooks, J.L. 1957. The systematics of North American Daphnia. Mem. Conn. Acad. Arts Sci., 13: 1-180.

Brooks, J.L. \& S.I. Dodson. 1965. Predation, body size and composition of plankton. Science, 150: 28-35.

Colbourne, J.K., T.J. Crease, L.J. Weider, P.D.N. Hebert, F. Dufresne, \& A. Hobiek. 1998. Phylogenetics and evolution of a circumarctic species complex (Cladocera: Daphnia pulex). Biol. J. Linn. Soc., 65: 347-366.

Dodson S.I. 1974. Zooplankton competition and predation: an experimental test of the size efficiency hypothesis. Ecology, 55: 605-613

Dodson, S.I. 1984. Predation of Heterocope septentrionalis on two species of Daphnia: morphological defenses and their cost. Ecology, 65: 1249-1257.

Dussart, B. 1969. Les copépodes des eaux continentales d'Europe occidentale. N. Boubée \& Cie, Paris: 292 pp.

Eby, L.A., W.J. Roach, L.B. Crowder \& J.A. Stanford. 2006. Effects of stocking-up freshwater food webs. Trends Ecol. Evol., 21: 576- 584.

Edmondson, W.T. 1955. The seasonal life history of Daphnia in an arctic lake. Ecology, 36: 439-455.

Edmondson, W.T. \& G.G. Wiberg. 1971. A manual on methods for the assessment of secondary productivity in fresh waters. IBP Handbook No 17, Blackwell Scientific Pubblications, Oxford: 357 pp. 
Ferrari, I. 1967. Cosiderazioni sistematiche ed ecologiche sulla Daphnia middendorffiana di un lago della alta Val Bognaco. Mem. Ist. ital. Idrobiol., 22: 61-80.

Ferrari, I. 1970. Accrescimento individuale e ciclo stagionale della Daphnia middendorffiana in un lago alpino. Mem. Ist. ital. Idrobiol., 26: 41-84.

Giussani, G., R. De Bernardi, R. Mosello, I. Origgi \& T. Ruffoni. 1986. Indagine limnologia sui laghi alpini d'alta quota. Doc. Ist. ital. Idrobiol., 9: 1-415.

Goswami, S.C. 2004. Zooplankton methodology, collection \& identification - a field manual. National Institute of Oceanography, Dona Paula, Goa: 26 pp.

Haney, J.F. \& C. Buchanan. 1987. Distribution and biogeography of Daphnia in the Arctic. In: Peter, R.H. \& R. de Bernardi (Eds), Daphnia. Mem. Ist. ital. Idrobiol., 45: 77-105.

Harding, J.P. \& W.A. Smith. 1974. A key to the British Freshwater Cyclopoid and Calanoid Copepods. $2^{\text {nd }}$ Ed., Sci. Publ., 218. Freshwater Biological Association, Westmorland: $54 \mathrm{pp}$.

Hebert, P.D.N. 1981. Obligate Asexuality in Daphnia. Am. Nat., 117: 784-789.

Hellich, B. 1877. Die Cladoceren Böhmens. Arch. Naturwiss. Landesdurchforshung Böhmen, 3: 20-40.

Hilliard, D.K. \& J.C. Tash. 1966. Freshwater algae and zooplankton. In: Wilmovsky N.J. \& Wolfe J.N. (Eds), Environment of the Cape Thompson Region, Alaska. U.S. Atomic Energy Comm. Div. Tech. Info.: 363-413.

Hobaek, A. \& L.J. Weider. 1999. A circumpolar study of arctic biodiversity: phylogeographic patterns in the Daphnia pulex complex. Ambio, 28: 245-250.

Holzapfel, A.M. \& R.D. Vinebrooke. 2005. Environmental warming increases invasion potential of Alpine lake communities by imported species. Glob. Change Biol., 11: 2009-2015.

Knapp, R.A., K.R. Matthews \& O. Sarnelle. 2001. Resistance and resilience of Alpine lake fauna to fish introductions. Ecol. Monogr., 71: 401-421.

Leporati, P., G.E. Mortara \& M. Giardino. 1999. L'assetto idrogeologico. In: AA. VV. Studi propedeutici per il Piano del Parco. Parco Nazionale Gran Paradiso, Aosta: 175 pp.

Luecke, C. \& W.J. O'Brien. 1983. The effect of Heterocope predation on zooplankton communities in arctic ponds. Limnol. Oceanogr., 28: 367-377.

Magnuson, J.J., K.E. Webster, R.A. Assel, C.J. Bowser, P.J. Dillon, J.G. Eaton, H.E. Evans, E.J. Fee, R.I. Hall, L.R. Mortsch, D.W. Schindler \& F.H. Quinn. 1997. Potential effects of climate changes on aquatic systems: Laurentian Great Lakes and Precambrian Shield Region. Hydrol. Process., 11: 825-871.

Manca, M. \& M. Armiraglio. 2002. Zooplankton of 15 lakes in the Southern Central Alps: comparison of recent and past (pre-ca 1850 AD) communities. J. Limnol., 61: 225-231.

Manuilova, E.F. 1964. Vetvistousye ruchki (Cladocera) faune SSSR. Opredeliteli po Faune SSSR, Izdatel'stvo Akademii Nauk SSSR, 88: 1-328.

Margaritora, F. 1985. Cladocera. Fauna d'Italia, Edizioni Calderini, Bologna: 399 pp.

O'Brien, W.J. 1987. Planktivory by freshwater fish: Thrust and Parry in the Pelagia. In: Kerfoot W. C. \& Sih A. (Eds), Predation. direct and indirect impacts on acquatic communities. University Press of New England, Hanover: pp. 3-16.

Paland, S., J.K. Colbourne \& M. Lynch. 2005. Evolutionary history of contagious asexuality in Daphnia pulex. Evolution, 59: 800-813.

Received: December 2010

Accepted: February 2011
Pinheiro, J., D. Bates, S. DebRoy, D. Sarkar and the R Development Core Team. 2010. nlme: Linear and Nonlinear Mixed Effects Models. R package version 3.1-97.

Poulsen, E.M. 1940. Biological remarks on Lepidorus arcticus Pallas, Daphnia pulex de Geer and Chydorus sphaericus O.F.M. in East Greenland. Medd. Gronl., 131: 1-50.

R Development Core Team. 2010. R: A language and environment for statistical computing. R Foundation for Statistical Computing, Vienna, Austria.

Scotta, M., P. Varese, R. Sindaco, G. Della Beffa. 1999. La flora, la vegetazione e la fauna. In: AA. VV., Studi propedeutici per il Piano del Parco, Aosta: 175 pp.

Stella, E. 1984. Copepoda: Calanoida (d'acqua dolce). Fauna d'Italia, Edizioni Calderoni, Bologna: $101 \mathrm{pp}$.

Stross, R.G., M.G. Miller \& R.J. Daley. 1980. Zooplankton. In: Hobbie J.E. (Ed.), Limnology of tundra ponds. Dowden, Hutchinson \& Ross, Inc. Stroudsburg PA: 251-296.

Thompson, P.L., M.C. St-Jacques \& R.D. Vinebrooke. 2008. Impacts of climate warming and nitrogen deposition on Alpine plankton in and pond habitats: an in vitro experiment. Arct. Antarct. Alp. Res., 40: 192-198.

Tiberti, R., G. Tartari \& A. Marchetto. 2010. Geomorphology and hydrochemistry of 12 Alpine lakes in the Gran Paradiso National Park, Italy. J. Limnol., 69: 242-256.

Tonolli, V. \& L. Tonolli. 1951. Osservazioni sulla biologia ed ecologia di 170 popolamenti zooplanctonici di laghi italiani d'alta quota. Mem. Ist. ital. Idrobiol., 6: 53-136.

Vega, M.P. \& A. Clause. 2000. Morphometry and cyclomorphosis in Daphnia middendorffiana from a fishless pond of the Southern Andes. J. Freshwat. Ecol., 15: 329-338.

Weider, L.J. \& A. Hobaek. 1994. Molecular biogeography of clonal lineages in a high-arctic apomictic Daphnia complex. Mol. Ecol., 3: 497-506.

Weider, L.J. \& A. Hobaek. 1997. Postglacial dispersal, glacial refugia, and clonal structure in Russian/Siberian populations of the arctic Daphnia pulex complex. Heredity, 78: 363-372.

Weider, L.J. \& A. Hobaek. 2003. Glacial refugia, haplotype dis- tributions, and clonal richness of the Daphnia pulex complex in Arctic Canada. Mol. Ecol., 12: 463-473.

Weider, L.J., A. Hobaek, P.D.N. Hebert \& T.J. Crease. 1999a. Holarctic phylogeography of an asexual species complexII. Allozymic variation and clonal structure in Arctic Daphnia. Mol. Ecol., 8: 1-13.

Weider, L.J., A. Hobaek, J.K. Colbourne, T.J. Crease, F. Dufresne, P.D.N. Hebert. 1999b. Holarctic phylogeography of an asexual species complex I. Mitochondrial DNA variation in Arctic Daphnia. Evolution, 53: 777-792.

Wilhelm, F.M., A.K. Hardie, A.S. McNaught \& S.L. Clare. 1998. Large suprabenthic Daphnia middendorffiana from an Alpine lake in the Canadian Rocky Mountains. Can. Field Nat., 112: 419-424.

Yurista, P.M. 1999. Temperature-dependent energy budget of an Arctic Cladoceran, Daphnia middendorffiana. Freshwat. Biol., 42: 21-34.

Yurista, P.M. \& W.J. O'brien. 2001. Growth, survivorship and reproduction of Daphnia middendorffiana in several Arctic lakes and ponds. J. Plankton Res., 23: 733-744.

Zaffagnini, F. \& B. Sabelli. 1972. Karyologic observations on the maturation of the summer and winter eggs of Daphnia pulex and Daphnia middendorffiana. Chromosoma, 36: 193-203.

Zuur, A.F., E.N. Ieno, N.J. Walker, A.A. Saveliev \& G.M. Smith. 2009. Mixed effect models and extensions in ecology with $R$. Springer, New York: 574 pp. 